\title{
Epidemiological Distribution of Mycoplasma gallisepticum in Haryana, India
}

\author{
Vaishali $^{{ }^{*}}$, Davinder Singh ${ }^{2}$ and Renu Gupta ${ }^{1}$ \\ ${ }^{1}$ Department of Veterinary Public Health and Epidemiology, LUVAS, Hisar, India \\ ${ }^{2}$ Extension Specialist, Directorate of Extension Education, LUVAS, Hisar, India \\ *Corresponding author
}

\section{Keywords}

Mycoplasma gallisepticum,

Avian

mycoplasmosis,

colibacillosis,

bronchits

Article Info

Accepted:

22 December 2019

Available Online:

20 January 2020
Avian mycoplasmosis is one of the most prevalent problem of poultry industry leading to heavy economic losses. Out of the various identified species of Mycoplasma, Mycoplasma gallisepticum is the principle causative agent of Chronic Respiratory disease (CRD). A variety of factors are responsible for the heavy death rates, including bird handling, age of flock, ventilation facilties, location of the farm, vaccination status of the birds, transportation, various environmental factors. CRD can be found in association with other infections like avian influenza, colibacillosis, New castle disease and infectious bronchits further causing complications. A significant difference was observed in the infection by Mycoplasma gallisepticumin birds of different age group $(\mathrm{p}=0.004)$. The infection appeared in an increasing order being highest in $>21$ days old $(43.75 \%)$ and lowest in birds of 0-7 days age (10.39\%).

\section{Introduction}

The most common causes of high mortality in poultry birds is due to respiratory distress, heat stress and E.coli infections. Avian mycoplasmosis is one of the most prevalent poultry problem affecting the industry economically. The Respiratory disease complex has contributed to heavy economic loses and it comprises cluster of factors responsible for the spread of disease and affecting mortality among the birds comprising of bird handling, viral, mycoplasma, age of flock, ventilation facilities, location of farm, vaccination, transportation, agro climatic zone, no. of farms in $1 \mathrm{~km}^{2}$ area and various environmental factors like temperature, high ammonia concentration and others. Mycoplasma gallisepticum is the principle causative agent of Chronic respiratory disease (CRD). Within intensive poultry farming, infection by CRD is found in association with avian influenza, Newcastle disease, colibacillosis and 
infectious bronchitis and further leads to more severe problems (Stipkovits et al., 2012). Mycoplasma gallisepticum vary from asymptomatic to severe symptoms like reduced feed efficiency, reduced egg production and decreased growth rate. Infections by Mycoplamsa gallisepticum causes loss of $10-20 \%$ decrease in egg production for a period of upto 1 month in layers (Pattinson et al., 2008).

\section{Material and Methods}

\section{Sample Collection}

A total of 100 samples were collected from seven different districts of Haryana. Bhiwani $(n=2)$, Hisar $(n=9)$, Jhajjar $(n=19)$, Jind $(n=20)$, Karnal $(n=20)$, Panipat $(n=23)$ and Sonepat $(n=7)$. Trachea, lungs and air sacs were collected from poultry flocks and were pooled, and together known as "sample". The samples were collected along with a questionnaire to be filled including questions like total birds on farm, no of birds affected, no of birds died, ventilation facilities, no. of farms in $1 \mathrm{~km}^{2}$ area, agro climatic zone, flock size, distance from nearby road, location of farm. The co-ordinates of farm were analysed by installing a app on smart phone "ODK collect". The location was mapped through QGIS software. The statistical analysis was carried out by STATA.

\section{Results and Discussion}

\section{Age of Flock}

The maximum number of samples positive for M. gallisepticum were observed in birds of $>10$ weeks of age i.e. $30.77 \%$ and least in birds of $>2-6$ weeks of age i.e. $10.61 \%$.

There was no significant difference among flocks of different age with respect to detection of MG (p-0.133) (Table 1).

\section{District}

The maximum cases positive for $\mathrm{MG}$ were observed in samples collected from Jind district i.e. $40 \%$ and there was no samples positive from Sonepat district. There was no significant difference among samples from different districts for detection of $M$. gallisepticum. (p- 0.230) (Table 1).

\section{Zone}

There was no significant difference between zones of Haryana with respect to detection of MG (p- 0.223) (Table 1). The samples collected from western zone gave a higher percentage than eastern zone i.e. $23.33 \%$.

\section{Flock Size}

The highest number of cases were reported in the medium flocks $(>10,000-30,000)$ i.e. $20.00 \%$ followed by cases on the small farm $(<10,000)$ i.e. $14.81 \%$ and no cases was reported positive for $\mathrm{MG}$ in the large flock $(>30,000)$. There was no significant difference between the farm size with respect to detection of M.gallisepticum (p- 0.873) (Table 1).

\section{Duration of Respiratory problems}

There was a significant association between duration of start of respiratory problem with respect to cases positive for MG (p- 0.004) (Table 1). The maximum number of cases were seen in birds suffering from respiratory problem for $>21$ days $43.75 \%$ and the minimum number of cases were seen in birds suffering from respiratory problem from 0-7 days i.e. $10.39 \%$.

\section{Use of antibiotic in last 1 month}

There was no significant association between use of antibiotic with respect to detection of 
M. gallisepticum.(p- 0.729) (Table 1).The number of cases seen positive for MG were more in the flocks where antibiotic were not used i.e. $16.67 \%$ and number of cases declined in flocks that used antibiotic i.e. $13.64 \%$.

\section{Location of farm}

There was no significant association between location of farm with respect to detection of M. gallisepticum (p- 0.312) (Table 1). The maximum percent for cases positive for $\mathrm{MG}$ were in urban areas i.e. $33.33 \%$ followed by cases in semi urban i.e. $21.43 \%$. The least number of cases were observed in rural areas i.e. $14.46 \%$.

\section{No. of farms in $1 \mathrm{Km}^{2}$ area}

There was no significant association between no. of farm in $1 \mathrm{~km}^{2}$ area with respect to detection of $M$. gallisepticum (p- 0.950)
(Table 1). The maximum percent of cases were more in $>6-10$ i.e. $20.00 \%$ followed by $1-5$ i.e. $15.73 \%$ and no cases were seen in $>10$.

\section{Ventilation facilities}

There was no significant association between ventilation facilities respect to detection of $M$. gallisepticum (p- 0.743; Table 2). The percantage of occurrence $M$. gallisepticum was same in both "only fan/cooler" and "only exhaust" i.e. $25 \%$. The least occurrence was seen in "both fan/cooler+ exhaust" i.e. $12.12 \%$.

\section{Distance from nearby road}

There was no significant association between distance from nearby road with respect to detection of MG (p- 0.533; Table 2). The samples positive for MG were more in $0-1 \mathrm{~km}$ i.e. $16.85 \%$ and less in $>1-3 \mathrm{~km}$ i.e. $9.09 \%$.

Table.1 Association of different parameters with detection of Mycoplasma gallisepticum in poultry with respiratory problems in Haryana

\begin{tabular}{|c|c|c|c|c|c|}
\hline & & $\begin{array}{l}\text { Positive for } \\
\text { Mycoplasma } \\
\text { gallisepticum }\end{array}$ & & Wald $\chi^{2}$ & $\mathbf{P}$ \\
\hline Variable & Category & $(\%)$ & $95 \% \mathrm{CI}$ & & \\
\hline \multicolumn{6}{|l|}{ PCR Results } \\
\hline & 100 & $16(16.00)$ & $9.43-24.68$ & & \\
\hline \multirow[t]{5}{*}{ Age of Flock } & & & & 2.26 & 0.133 \\
\hline & 0-2 week (4) & $1(25.00)$ & $0.63-80.59$ & & \\
\hline & $>2-6$ wk (66) & $7(10.61)$ & $4.37-20.64$ & & \\
\hline & $>6-10$ wk (17) & $4(23.53)$ & $6.81-49.90$ & & \\
\hline & $>10$ wk (13) & $4(30.77)$ & $9.09-61.43$ & & \\
\hline \multirow[t]{8}{*}{ District } & & & & 1.44 & 0.230 \\
\hline & Bhiwani (2) & $1(50.00)$ & $1.26-98.74$ & & \\
\hline & Hisar (9) & $1(11.11)$ & $0.28-48.25$ & & \\
\hline & Jhajjar (19) & $1(5.26)$ & $0.13-26.03$ & & \\
\hline & Jind (20) & $8(40.00)$ & $19.12-63.95$ & & \\
\hline & Karnal (20) & $3(15.00)$ & $3.21-37.89$ & & \\
\hline & Panipat (23) & $2(8.70)$ & $1.07-28.04$ & & \\
\hline & Sonepat (7) & 0 & $0.00-40.96$ & & \\
\hline Zone & & & & 1.49 & 0.223 \\
\hline
\end{tabular}




\begin{tabular}{|c|c|c|c|c|c|}
\hline & Eastern (70) & $9(12.86)$ & $6.05-23.01$ & & \\
\hline & Western (30) & $7(23.33)$ & $9.93-42.28$ & & \\
\hline \multirow[t]{4}{*}{ Flock size } & & & & 0.03 & 0.873 \\
\hline & $\begin{array}{l}\text { Small }-\leq 10,000 \\
(54)\end{array}$ & $8(14.81)$ & $6.62-42.28$ & & \\
\hline & $\begin{array}{l}\text { Medium- } \\
>10,000- \\
30000(40)\end{array}$ & $8(20.00)$ & $9.05-35.65$ & & \\
\hline & $\begin{array}{l}\text { Large->30,000 } \\
\text { (6) }\end{array}$ & 0 & $0.00-45.93$ & & \\
\hline \multirow{4}{*}{$\begin{array}{l}\text { Duration of } \\
\text { respiratory } \\
\text { problems }\end{array}$} & & & & 8.42 & 0.004 \\
\hline & $0-7$ days (77) & $8(10.39)$ & $4.59-19.45$ & & \\
\hline & 8-21 days (7) & $1(14.29)$ & $0.36-57.87$ & & \\
\hline & $>21$ days $(16)$ & $7(43.75)$ & $19.75-70.12$ & & \\
\hline \multirow{3}{*}{$\begin{array}{l}\text { Use of } \\
\text { antibiotics } \\
\text { during last } 1 \\
\text { month }\end{array}$} & & & & 0.12 & 0.729 \\
\hline & Yes (78) & $3(13.64)$ & $2.91-34.91$ & & \\
\hline & No (22) & $13(16.67)$ & $9.18-26.81$ & & \\
\hline \multirow{4}{*}{$\begin{array}{l}\text { Location of } \\
\text { farm }\end{array}$} & & & & 1.02 & 0.312 \\
\hline & Rural (83) & $12(14.46)$ & $7.70-23.89$ & & \\
\hline & $\begin{array}{l}\text { Semi-urban } \\
\text { (14) }\end{array}$ & $3(21.43)$ & $4.66-50.80$ & & \\
\hline & Urban (3) & $1(33.33)$ & $0.84-90.57$ & & \\
\hline \multirow{4}{*}{$\begin{array}{l}\text { No. of farms } \\
\text { in } 1 \mathrm{Km}^{2} \text { area }\end{array}$} & & & & 0.00 & 0.950 \\
\hline & $1-5(89)$ & $14(15.73)$ & $8.88-24.98$ & & \\
\hline & 6-10 (10) & $2(20.00)$ & $2.52-55.61$ & & \\
\hline & $>10(1)$ & 0 & $0.00-97.5$ & & \\
\hline \multirow{5}{*}{$\begin{array}{l}\text { Ventilation } \\
\text { facilities }\end{array}$} & & & & 0.11 & 0.743 \\
\hline & Natural (51) & $8(15.69)$ & $7.02-28.59$ & & \\
\hline & $\begin{array}{l}\text { Only } \\
\text { Fan/Cooler (8) }\end{array}$ & $2(25.00)$ & $3.18-65.09$ & & \\
\hline & $\begin{array}{l}\text { Only Exhaust } \\
\text { (8) }\end{array}$ & $2(25.00)$ & $3.18-65.09$ & & \\
\hline & $\begin{array}{l}\text { Both } \\
\text { Fan/Cooler + } \\
\text { Exhaust (33) }\end{array}$ & $4(12.12)$ & $3.40-28.20$ & & \\
\hline \multirow{3}{*}{$\begin{array}{l}\text { Distance } \\
\text { from nearby } \\
\text { road }\end{array}$} & & & & 0.39 & 0.533 \\
\hline & 0-1 Km (89) & $15(16.85)$ & $9.75-26.27$ & & \\
\hline & $>1-3 \mathrm{Km}(11)$ & $1(9.09)$ & $0.22-41.28$ & & \\
\hline
\end{tabular}


There was no significant association between detection of Mycoplasma gallisepticum with respect to age as per our study. Maximum cases of MG were reported in birds aged $>10$ weeks i.e. $30.77 \%$, followed by $25.00 \%$ in $0-2$ weeks, $23.53 \%$ in $>6-10$ weeks and least in $>2-6$ weeks i.e. $10.61 \%$. Similar to our study, Singh et al. (2016) reported maximum prevalence by Mycoplasma gallisepticum in the age group of 6-12 weeks i.e. $40 \%$ and Ahmad et al. (2008) in Lahore also reported the highest prevalence of MG in 12-17 week age group i.e. $78.12 \%$. Asgharzadeet al. (2012) in Iran reported maximum prevalence of MG in age group of 6-7 week. Hossain et al. (2007) in Bangladesh reported maximum prevalence of MG in birds of 18-25 weeks of age. Sarkar et al. (2005) recorded highest $73.80 \% \mathrm{MG}$ infection at 20 weeks of age in comparison to lowest $45.16 \%$ at 55 weeks of age. Tahla 2003 gave similar results showing the prevalence of $\mathrm{MG}$ decreased as the age increased. Heleiliet al. (2012) showed similar results and reported significantly higher prevalence of $\mathrm{MG}$ in young birds rather than adult indicating 75\% MG in layers aged 8-16 weeks and 92.59\% MG in broilers aged 4-6 weeks.

\section{References}

Ahmad, A., Rabbani, M., Yaqoob, T., Ahmad, A., Shabbir M.Z. and Akhtar., F. 2008. Status of IGg antibodies against Mycoplasma gallisepticum in nonvaccinated commercial poultry breeder flocks. J. Anim. Pl. Sci.18: 2-3.

Asgharzade, S., Zaeri, S., Hasanzade, M., Ahmadi, M. and Talebi, A.R. (2012). Detection of Mycoplasma gallisepticum in experimentally infected broiler chickens using Culture, SPA, ELISA, and PCR methods. Comp ClinPathol. Doi 10.1007/s00580-012-1524-4.

Heleili, N., Ammar, A., Mamache, B. and Chelihi, A.J. (2012). Seroprevalence of
Mycoplasam gallisepticum and Mycoplasma synoviae at BatnaCommerical Poultry farm in Algeria. Veterinary World. 5(12): 709712.

Hossain, K.M.M., Ali, M.Y. and Haque, M.I. (2007).Seroprevalence of Mycoplasma gallisepticum infections in Chicken in Greater Rajshahi Districts of Bangladesh. Bangl. J. Vet. Med. 5(1\&2): 09-14.

OIE. (2008). Manual of Diagnostic tests and Vaccines for Terrestrial Animals. Chapter 2.3.5: Avian mycoplasmosis (Mycoplasma gallisepticum, M. synoviae), pp. 482-496.

Pattinson, M., McMullin, P. F., Bradbury, J. M. and Alexander, D.J. (2008). Avian mycoplasmosis. In.: Poultry diseases $\left(6^{\text {th }}\right.$ edn.). Saunders Elsevier, Missouri, USA.

Raviv, Ziv, Callison, S.N., Ferguson-Noel, Laibinis, V., Wooten, $\mathrm{R}$ and Kleven, S.H. 2007. The Mycoplasma gallisepticum 16S-23S rRNA Intergenic Spacer Region Sequence asa Novel Tool for Epizootiological Studies. Avian dis., 51:555-560.

Sarkar, S.K., Rahman ,M.B., Rahman, M., Amin, K.M.R., Khan, M.F.R. and Rahman, M.M. (2005). Sero-prevalence of Mycoplasma galliseplicum infection in chickens in model breeder poultry farms of Bangladesh. International Journal of Poultry Science.4(1): 32-35.

Singh, N., Shukla, S. and Sharma, V. (2016). Detection of Anti Mycoplasma gallisepticum Antibodies in Different Age Group of Chicken by Enzyme Linked Immunosorbant Assay. Journal of Animal Research.6(1):49-51.

Stipkovits, L.,Glavits, R., Palfi, V., Beres, A., Egyed, L., Denes, B., Somogyi, M. and Szathmary, S. (2012). Pathologic lesions caused by coinfection of Mycoplasma gallisepticum and H3N8 low pathogenic 
avian influenza virus in chickens. Vet. Pathol. 49(2): 273-283.

Talha AFSM (2003). Investigation on the prevalence of Mycoplasma gallisepticum in village chickens and possibility of establishing Mycoplasma gallisepticum free flocks and significance Mycoplasma gallisepticum of different production parameters in layer chickens in Bangladesh. M.Sc. Thesis, Department of Veterinary Microbiology, the Royal Veterinary and Agricultural University, Denmark and Department of Pathology, Bangladesh Agricultural University, Mymensing, Bangladesh.

\section{How to cite this article:}

Vaishali, Davinder Singh and Renu Gupta. 2020. Epidemiological Distribution of Mycoplasma gallisepticum in Haryana, India. Int.J.Curr.Microbiol.App.Sci. 9(01): 2512-2517. doi: https://doi.org/10.20546/ijcmas.2020.901.285 